\title{
Implementasi Kebijakan Pemerintah Kota Mataram Untuk Meningkatkan Kesejahteraan Gelandangan di Dinas Sosial
}

\author{
Zaini Bidaya', Ahmda Muzaini²
}

\author{
${ }^{1}$ Pendidikan Pancasila dan Kewarganegaraan, Universitas Muhammadiyah Mataram, Email: zainibidaya@gmail.com \\ ${ }^{2}$ Pendidikan Pancasila dan Kewarganegaraan, Universitas Muhammadiyah Mataram, Email: ahmadmuzaini14@gmail.com
}

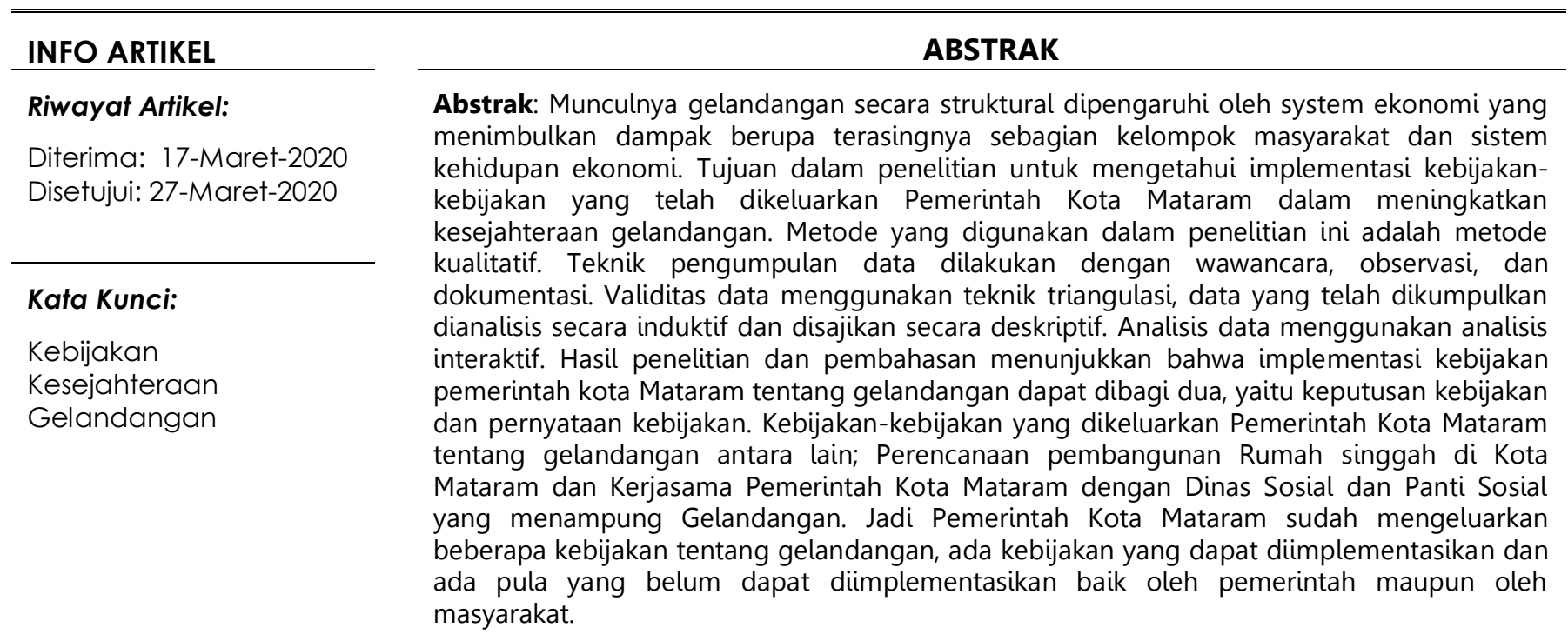

\begin{abstract}
The emergence of bums is structurally influenced by the economic system that has an impact on the terracing of some communities and the system of economic life. The purpose of the study is to know the implementation of policies that have been issued by the Mataram city government in improving the welfare of the city of Mataram. The method used in this research is a qualitative method. Data collection techniques are conducted with interviews, observations, and documentation. The validity of the data using the triangulation technique, the data that has been collected is analyzed inductive and presented descriptively. Analyze data using interactive analysis. The results of the research and discussion show that the implementation of Mataram city government policy about the tramp can be divided into two, namely policy decision and policy statement. Policies issued by the Mataram city government on bums include; Planning for the development of Rumah stopover in Mataram City and the cooperation of Mataram city government with social service and social orphanage that holds the tramp. So the Mataram city government has issued some policies on homeless, there are policies that can be implemented and some are not able to be implemented by both government and community.
\end{abstract}

\section{A. LATAR BELAKANG}

Kota Mataram, adalah salah satu kota besar di Indonesia, Ibukota Nusa Tenggara Barat (NTB), pusat segala aktivitas ekonomi, sosial dan budaya. Seperti halnya kota-kota lain yang sedang berkembang di seluruh dunia, Mataram juga merasakan fenomena yang serupa. Perkembangan pesat, seperti berdirinya kantorkantor, pusat perbelanjaan, sarana perhubungan, pabrik, sarana hiburan dan sebagainya tak pelak mendorong para urban untuk mengadu nasib. Bagi mereka yang mempunyai bekal ilmu pengetahuan dan keterampilan yang cukup bukan tidak mungkin mereka mampu bertahan di kota ini. Tapi sebaliknya, bagi mereka yang belum beruntung bukan tidak mungkin pula mereka menyambung hidupnya dengan menjadi gelandangan atau pengemis. Munculnya gelandangan secara struktural dipengaruhi oleh system ekonomi yang menimbulkan dampak berupa terasingnya sebagian kelompok masyarakat dan sistem kehidupan ekonomi. Kaum gelandangan membentuk sendiri Sistem kehidupan baru yang kelihatannya berbeda dari sistem kehidupan ekonomi kapitalistis. Munculnya kaum gelandangan ini diakibatkan oleh pesatnya perkembangan kota yang terjadi secara paralel dengan tingginya laju urbanisasi [1]. 
Penelitian ini didasari penelitian yang berpendapat bahwa penyelesaian masalah gelandangan adalah memproduksi kebijakan dan melakukan tindakan dnegan mempertimbangkan sector eksternal yaitu penyebab kegelandangan itu sendiri dengan pendekatan ekonomi-politik-struktural dan menyusun program pembinaan yang berorientasi pada productive value, dan tidak sekedar exchangeable value [2]. Pemerintah kota Semarang telah menerapkan Peraturan Daerah Kota Semarang Nomor 5 Tahun 2014 tentang Penanganan Anak Jalanan, Gelandangan dan Pengemis pada tahun 2014 sebagai dasar hukum bagi penanganan anak jalanan, gelandangan dan pengemis di Kota Semarang. Dua dinas yang bidang social dan kepemudaan telah menerapkan dengan mencanangkan program-program penanganan baik dalam hal pencegahan, pembinaan maupun rehabilitasi [3]. Selanjutnya program penangan gelandangan, anak jalanan, pengemis dapat dilakukan program ekonomi kreatif desa, hal ini lakukan anakanak terlantar tersebut mampu menciptakan karya, ekonomi yang mandiri [4]. Ketiga penelitian tersebut pada umumnya peraturan atau kebijakan daerah yang telah diterapkan tentang peanganan gelandangan yang digunakan belum efektif karena anak gelandangan masih saja berkeliaran dimana-mana terutama di tempat pelayanan umum, program ekonomi kreatif desa memang cukup mengurangi pengangguran pada anak gelandangan akan tetapi tidak maksimal.

Atas dasar itulah, maka penelitian yang akan dilakukan dalam penelitian ini, mengkaji kesejahteraan gelandangan. Kesejahteraan gelandangan ini sangat penting dilakukan untuk dapat memberikan solusi efektif dalam mengatasi gelandangan. Oleh karena itu, bahwa pemerintah kota Mataram memiliki aturan tentang penanganan anak gelandangan melalui Rumah Singgah. Rumah singgah ini sebagai tempat rehabilitasi anak gelandangan dengan berbagai kegiatan yang meningkatkan kesejahteraan gelandangan.

Masalah sosial gelandangan dan pengemis merupakan fenomena social yang tidak bisa dihindari keberadaannya dalam kehidupan masyarakat, terutama yang berada di daerah perkotaan (kota-kota besar). Salah satu factor yang dominan mempengaruhi perkernbangan masalah ini adalah kemiskinan. Masalah kemiskinan di Indonesia berdampak negatif terhadap meningkatnya arus urbanisasi dari daerah .pedesaan ke kota-kota besar, sehingga terjadi kepadatan penduduk dan daerah-daerah kumuh yang menjadi pemukiman para urban tersebut. Sulit dan terbatasnya lapangan pekerjaan yang tersedia, serta terbatasnya pengetahuan dan keterampilan menyebabkan mereka banyak yang mencari nafkah untuk mempertahankan hidup dengan terpaksa menjadi gelandangan atau pengemis.

Jumlah gelandangan dari tahun ke tahun semakin meningkat, terlebih sejak krisis ekonomi yang melanda bangsa Indonesia tahun 1997. Berdasarkan data dari pusat Data dan Informasi Kesejahteraan Sosial (Pusdatin Kesos) Departemen Sosial RI tahun 2000, diluar propinsi Maluku dan Nanggroe Aceh Darussalam populasi gelandangan dan pengemis seluruh Indonesia berjumlah 72.646 orang. Kemudian tahun 2002 mengalami peningkatan sehingga populasinya menjadi 85.294 orang[5]. Dan Menurut data terbaru yang dilansir Badan Pusat Statistik (BPS), jumlah penduduk miskin di Indonesia per Maret 2011 berjumlah 30,02 juta atau 12,49 persen dari total penduduk. Jika dibandingkan dengan data Maret 2010 berjumlah 31,02 juta jiwa atau sekitar 13,33 persen dari total penduduk Indonesia memang terjadi penurunan walaupun tidak signifikan yaitu sebesar o,84 persen [6].

Gelandangan merupakan sekelompok masyarakat yang terasing, karena mereka ini lebih sering dijumpai dalam keadaan yang tidak lazim, seperti di kolong jembatan, di sepanjang lorong-lorong sempit, di sekitar pinggir sungai ataupun di setiap emper-emper toko, dan dalam hidupnya sendiri mereka ini akan terlihat sangat berbeda dengan manusia merdeka lainnya [7].

Peran pemerintah dalam menangani masalah sosial gelandangan sangat penting, sebagaimana yang diamanatkan dalam Pasal 27 Ayat (2) dan Pasal 34 Ayat (1) Undang-Undang Dasar Negara Republik Indonesia Tahun 1945 Amandemen keempat. Pasal 27 Ayat (2) Undang-Undang Dasar 1945 Amandemen keempat berbunyi : "Tiap-tiap warga negara berhak atas pekerjaan dan penghidupan yang layak bagi kemanusiaan"[8]. Pasal 34 ayat (1) Undang-Undang Dasar 1945 Amandemen keempat yang berbunyi "Fakir miskin dan anak terlantar di pelihara oleh negara". Pasal tersebut memberikan pengertian pula bahwa tujuan negara sebagaimana tercantum dalam alinea keempat Pembukaan Undang-Undang Dasar 1945, adalah Negara tidak dapat melepaskan tanggung jawabnya untuk memelihara fakir miskin dan anak-anak terlantar.

Sampai saat ini gelandangan dianggap sebagai perbuatan pidana. Hal ini tercerminkan dari bunyi Pasal 505 Kitab Undang-Undang Hukum Pidana sebagai berikut: "Ayat (1) Barang siapa bergelandangan tanpa mata pencaharian, diancam karena melakukan pergelandangan dengan kurungan paling lama tiga bulan. Ayat (2) Pergelandangan yang dilakukan oleh tiga orang atau lebih, yang umurnya di atas enam belas tahun, diancam dengan kurungan paling lama enam bulan”.

Pasal di atas jelas menganggap gelandangan sebagai suatu tindakan yang melanggar hukum. Akan tetapi pemerintah tidak dapat menyikapi masalah sosial gelandangan itu hanya dengan memberikan hukuman karena masalah sosial gelandangan merupakan tanggung jawab pemerintah, sesuai yang diamanatkan Pasal 27 ayat (2) UUD 1945 yang menyatakan “ Tiap tiap warga negara berhak atas pekerjaan dan penghidupan yang layak bagi kemanusiaan " dan 34 ayat (1) UUD 1945 menyatakan "Fakir miskin dan anak anak terlantar di 
pelihara oleh negara ". Untuk itu perlu adanya campur tangan Pemerintah, khususnya Pemerintah Kota Mataram untuk menanggulangi masalah gelandangan di kotanya.

Salah satunya dapat dilakukan dengan cara merumuskan kebijakan untuk menanggulangi masalah gelandangan tersebut. Karena semua masalah yang timbul merupakan agenda tetap pemerintah untuk mendapatkan penyelesaiannya dengan menuangkannya melalui kebijakan-kebijakan yang dibuat oleh pemerintah.

Kebijakan Pemerintah Kota Mataram untuk menangani gelandangan berdasarkan pada peraturan perundang-undangaan yang telah ada sebelumnya, yaitu Peraturan perundang-undangan yang berkaitan dengan kesejahteraan gelandangan antara lain; UU No. 6 Tahun 1974 tentang Kesejahteraan Sosial, dan Peraturan Pemerintah No. 31 Tahun 1980 tentang Penanggulangan Gelandangan dan Pengemis, serta menerapkan kebijakan daerah dengan membuat Rumah Singgah atau rumah penitipan anak seperti panti.

Kebijakan-kebijakan secara umum disesuai dengan tugas dan fungsi baik pemerintah pusat maupun daerah. Kebijakan negara yang dibuat para legislator pusat seperti undang-undang berlaku secara nasional dan terkadang dalam implementasinya di daerah akan dijalankan sesuai dengan kondisi daerah itu. Sebagai contoh, suatu Pemerintah Propinsi membuat aturan yang berlaku untuk daerahnya saja (Peraturan Daerah). Peraturan Daerah memang penting, dibuat untuk mengatur daerahnya, termasuk untuk mengatur masalah-masalah sosial seperti pemukiman kumuh, pengemis dan gelandangan, urbanisasi, pengangguran dan mungkin masalah anak jalanan dan anak terlantar.

Kebijakan yang diterapkan dibeberapa kota seperti kota semarang, dan kota Riau telah telah mengurangi dampak negative terhadap gelandangan, pengemis maupun anak jalanan dengan mencanangkan programprogram penanganan baik dalam hal pencegahan, pembinaan maupun rehabilitasi serta program pembinaan yang berorientasi pada productive value, dan tidak sekedar exchangeable value. Maka implementasi kebijakan pemerintah kota Mataram terhadap gelandangan menerapkan program rumah singgah dan meningkatkan kesejahteraan gelandangan melalui program lokakarya dan pemberdayaan. Dengan demikian focus kajian dalam penelitian kami adalah mengukur kesejahteraan gelandangan terhadap implementasi peraturan daerah pemerintah kota Mataram yaitu program rumah Singgah. Dalam penelitian ini tujuan yang harapkan menjelaskan kebijakan-kebijakan yang telah dikeluarkan pemerintah Kota Mataram dalam meningkatkan kesejahteraan gelandangan di Kota Mataram dan implementasinya.

\section{B. METODE PENELITIAN}

1. Metode dan pendekata penelitian

Penelitian ini menggunakan penelitian kualitatif dnegan pendekatan deskriptif, pendekatan ini untuk menjelaskan data-data lapangan secara holistik. Penelitian kualitatif lebih banyak ditujukan pada pembentukan teori sumatif berdasarkan dari konsepkonsep yang timbul dari data empiris.

\section{Lokasi Penelitian}

Lokasi penelitian dilakukan di Dinas Sosial Kota Mataram.

3. Informan dan responden

Adapun kriteria informan dan responden penelitian terdiri atas Kepala Bidang Pemberdayaan Kesejahteraan Sosial, Kepala Bidang Rehabilitasi dan Pelayanan Kesejahteraan Sosial dan Pegawai dari Dinas Sosial. Sedangkan informan berikutnya akan berlanjut sampai data informan didapatkan optimal.

\section{Metode Pengumpulan Data}

\section{a. Observasi}

Observasi dilakukan melalui pengamatan dan pencatatan sistematis terhadap gejala-gejala yang diteliti. Pengamatan dalam penelitian ini dilakukan terhadap kehidupan sosial gelandangan. Pengamatan ini dilakukan untuk mengetahui apakah kebijakan yang telah dikeluarkan oleh Pemerintah Kota Mataram benarbenar dapat mengatasi masalah sosial gelandangan demi meningkatkan kesejahteraan mereka.

b. Wawancara

Wawancara dalam penelitian ini dilakukan melalui wawancara sederhana dengan gelandangan di dalam panti dan gelandangan yang sudah kembali ke masyarakat mengenai asal mereka, sebab-sebab mereka menggelandang, serta keadaan keluarganya. Wawancara juga dilakukan dengan Staf Bagian Sosial Pemerintah Kota Mataram, Staf panti khusus gelandangan.

5. Sumber Data Penelitian

Data primer adalah data yang diperoleh langsung dari lapangan atau dari masyarakat. Data sekunder dalam penelitian ini diperoleh dengan cara: 1) Penelitian kepustakaan, penelitian kepustakaan yaitu suatu metode pengumpulan data dengan cara menggunakan dan mempelajari literatur buku - buku kepustakaan yang. ada untuk mencari konsepsi - konsepsi, teori - teori yang berhubungan erat dengan permasalahan. 2) Dokumentasi, dokumentasi[9] yaitu metode yang digunakan untuk mencari data mengenai hal - hal atau variabel yang berupa catatan, transkrip, buku, surat kabar, majalah, prasasti, notulen rapat, legger, agenda dan lain sebagainya.

\section{Validitas}

Validitas data menggunakan teknik triangulasi, data yang telah dikumpulkan dianalisis secara induktif dan disajikan secara deskriptif. 


\section{Analisis Data}

Tahapan analisis data menggunakan reduksi data, penyajian data dan penarikan kesimpulan serta verifikasi data.

\section{HASIL DAN PEMBAHASAN}

\section{Jumlah Gelandangan Kota Mataram}

Tabel 1

Jumlah Gelandangan di Kota Mataram

\begin{tabular}{lc}
\hline Kecamatan & Jumlah gelandangan \\
\hline Ampenan & 42 \\
Sekarbela & 20 \\
Mataram & 26 \\
Selaparang & 25 \\
Cakranegara & 42 \\
Sandubaya & 32 \\
Luar Kota Mataram & 9 \\
\hline Jumlah & 196 \\
\hline
\end{tabular}

Gelandangan Kota Mataram bukan saja berasal dari Mataram, tetapi mereka ada pula yang berasal dari luar Kota Mataram. mereka yang pernah terjaring Razia oleh SatPol PP, kemudian dibawa ke Dinas social Kota Mataram dan di salurkan ke Panti Sosial atau dikembalikan lagi ke keluarganya atau ke daerah tempat dia berasal.

\section{Implementasi Kebijakan Pemerintah Kota Mataram Tentang Gelandangan}

Implementasi kebijakan dalam mengatasi gelandangan, maka pemerintah kota Mataram telah membuat dan merencanakan kebijakan untuk menangani gelandangan, adapun kebijakannya dengan membuat Rumah Singgah atau rumah penitipan anak seperti panti, yaitu:

a. Pembuatan Rumah Singgah

Pembuatan Rumah Singgah merupakan langkah strategi untuk menampung anak jalanan, anak gelandangan maupun anak yatim piatu. Adapun rencana kebijakan pemerintah yakni:

"Pemerintah telah merencanakan akan membangun sebuah rumah singgah untuk para Gelandangan dan pengemis, tapi rencana itu sampai kini belum terealisasi tapi insyaAllah kami usahakan secepatnya" (Hasil wawancara Informan 1).

Sebagai Kepala seksi Rehabilitasi sosial dan Tuna Sosial menjelaskan bahwa untuk di kota mataram kami akan membangun rumah singgah untuk para Gelandangan, pengemis dan anak jalanan, berikut pernyataannya:

"supaya ada tempat menampung mereka setelah di razia. Pemerintah merencanakan akan membangun sebuah rumah singgah. Karena selama Kita merazia mereka kita hanya menampungnya di Panti sosial yang di bengkel itu dan sebagian di pulangkan dan di kasi penyuluhan di Kantor di sini" (Hasil wawancara Informan 2)

Rumah Singgah merupakan salah satu alternatif pemberdayaan Gelandangan, pengemis dan anak jalanan. Salah satu bentuk penanganan Gelandangan, pengemis dan anak jalanan adalah melalui pembentukan rumah singgah. Konferensi Nasional II Masalah pekerja Gelandangan pengemis da anaka jalanan di Indonesia pada bulan juli 1996 mendefinisikan rumah singgah sebagai tempat pemusatan sementara yang bersifat non formal, dimana para Gelandangan, pengemis dan anak jalanan bertemu untuk memperoleh informasi dan pembinaan awal sebelum dirujuk ke dalam proses pembinaan lebih lanjut.

Sedangkan menurut Departemen Sosial RI rumah singgah didefinisikan sebagai perantara Para gelandangan dan anak jalanan dengan pihak-pihak yang akan membantu mereka. Rumah singgah merupakan proses informal yang memberikan suasana pusat realisasi gelandangan dan anak jalanan terhadap system nilai dan norma di masyarakat.

Secara umum tujuan dibentuknya rumah singgah adalah membantu gelandangan dan anak jalanan mengatasi masalah-masalahnya dan menemukan alternatif untuk pemenuhan kebutuhan hidupnya. Sedang secara khusus tujuan rumah singgah adalah :

1) Membentuk kembali sikap dan prilaku gelandangan dan anak yang sesuai dengan nilai-nilai dan norma yang berlaku di masyarakat.

2) Mengupayakan gelandangan dan anak-anak kembali kerumah jika memungkinkan atau ke panti dan lembaga pengganti lainnya jika diperlukan.

3) Memberikan berbagai alternatif pelayanan untuk pemenuhan kebutuhan gelandangan dan anak dan menyiapkan masa depannya sehingga menjadi masyarakat yang produktif.

Peran dan fungsi rumah singgah bagi program pemberdayaan gelandangan dan anak jalanan di Kota Mataram sangat penting. Secara ringkas fungsi rumah singgah antara lain :

1) Sebagai tempat pertemuan (meeting point) pekerja social, gelandangan dan anak jalanan. Dalam hal ini sebagai tempat untuk terciptanya persahabatan dan keterbukaan antara gelandangan dan anak jalanan dengan pekerja sosial dalam menentukan dan melakukan berbagai aktivitas pembinaan.

2) Pusat diagnosa dan rujukan. Dalam hal ini rumah singgah berfungsi sebagi tempat melakukan diagnosa terhadap kebutuhan dan masalah gelandangan dan anak jalanan serta melakukan rujukan pelayanan social bagi gelandangan dan anak jalanan.

3) Fasilitator atau sebagai perantara gelandangan, anak jalanan dengan keluarga, keluarga pengganti, dan lembaga lainnya. 
4) Perlindungan. Rumah singgah dipandang sebagai tempat berlindung dari berbagai bentuk kekerasan yang kerap menimpa Gelandanganan dan anak jalanan dari kekerasan dan prilaku penyimpangan seksual ataupun berbagai bentuk kekerasan lainnya.

5) Pusat informasi tentang gelandangan dan anak jalanan Kota Mataram

6) Kuratif dan rehabilitatif, yaitu fungsi mengembalikan dan menanamkan fungsi social gelandangan dan anak jalanan.

7) Akses terhadap pelayanan, yaitu sebagai persinggahan sementara para gelandangan dan anak jalanan dan sekaligus akses kepada berbagai pelayanan social.

8) Resosialisasi. Lokasi rumah singgah yang berada ditengah-tengah masyarakat merupakan salah satu upaya mengenalkan kembali norma, situasi dan kehidupan bermasyarakat bagi gelandangan dan anak jalanan. Pada sisi lain mengarah pada pengakuan, tanggung jawab dan upaya warga masyarakat terhadap penanganan masalah gelandangan dan anak jalanan.

Berkaitan dengan basil penelitian tersebut maka teori yang mendukung implementasi kebijakan Pemerintah Kota Mataram dalam menangani gelandangan adalah termasuk dalam sifat kebijakan yang di kemukakan oleh Budi Winarno. Budi Winarno merinci sifat kebijakan menjadi lima kategori yaitu tuntutan-tuntutan kebijakan (policy demands), keputusan-keputusan kebijakan (policy decisions), pernyataan-pernyataan kebijakan (policy statements), hasil-hasil kebijakan (policy outputs), dan dampakdampak kebijakan (policy outcomes)[9].

Berkaitan dengan sifat kebijakan tersebut maka kebijakan Pemerintah Kota Mataram dalam menangani gelandangan termasuk dalam keputusan kebijakan (policy decisions). Keputusan kebijakan adalah keputusankeputusan yang dibuat oleh pejabat-pejabat pemerintah yang mengesahkan atau memberi arab dan substansi kepada tindakan-tindakan kebijakan publik. Termasuk dalam kegiatan $\mathrm{ml}$ adalah menetapkan undang-undang, memberikan perintah-perintah eksekutif atau pernyataan pernyataan resmi, mengumumkan peraturan-peraturan administratif atau membuat interpretasi yuridis terhadap UndangUndang[10].

Berdasarkan hash penelitian terungkap bahwa Pemerintah Kota Mataram dalam menangani gelandangan telah mengeluarkan keputusan kebijakan yaitu tentang Rencana Pembangunan Rumah singgah di kota Mataram. Implementasi kebijakan Pemerintah Kota Mataram tentang perencanaan pembangunan rumah singgah di Kota Mataram, dilaksanakan oleh Pemerintah Kota Mataram dengan melakukan penertiban, pelayanan dan rehabilitasi sosial bagi gelandangan Kota Mataram., yang salah satu tugasnya adalah menampung dan merehabilitasi gelandangan, pengemis dan anak jalanan di Kota Mataram.

Ketidaknyamanan psikis, merupakan kondisi yang menimbulkan seseorang atau kelompok masyarakat mengalami rasa takut ketika berhadapan secara langsung di jalan dengan gelandangan. Hal itu disebabkan karena penampilan keseharian mereka yang cenderung aneh. Sedangkan ketidaknyamanan sosial, merupakan kondisi yang tercipta di lapangan, di mana sebenarnya secara tidak sengaja telah terjadi perbedaan status sosial yang menggambarkan kondisi ketidakadilan. Iklim demikian akan memudahkan terciptanya konflik sosial diantara lapisan yang ditimbulkan. Konflik sosial yang berkepanjangan menciptakan tindakan kekerasan sebagai akibat tingkat konflik cenderung meningkat secara kuantitas maupun kualitas tanpa penyelesaian akhir. Salah satu factor penyebab tingginya kekerasan dalam masyarakat adalah masalah ekonomi. Kekerasan yang disebabkan oleh faktor ekonomi menempati skala frekuensi yang dominan disbanding kekerasankekerasan yang dilatarbelakangi oleh faktor non ekonomi [9].

Kebijakan Pemerintah Kota Mataram baik yang menyangkut pembangunan Rumah singgah dan pelaksanaan tugas Pihak Dinas Sosial sejauh ini dapat diimplementasikaan oleh para pelaksana kebijakan. Terbukti dalam bebarapa bulan dapat terlakasana razia, yang dalam pelaksanaannya pula bekerjasama dengan Satpol PP dan Kepolisian. Razia yang dilakukan oleh Pemerrntah Kota Mataram terhadap gelandangan tersebut bertujuan menciptakan keteraturan, keindahan, dan ketertiban secara umum. Razia juga bertujuan untuk memutus mata rantai kehidupan gelandangan agar kembali normal di tengah masyarakat. Akibat yang diharapkan, perilaku secara wajar dimiliki gelandangan sehingga tidak menggelandang lagi. Keberhasilan memutus mata rantai ini tentu saja dapat meningkatkan peran gelandangan di tengah masyarakat secara umum. Akibat yang ditimbulkan, perilaku produktif akan ditunjukkan gelandangan dibandingkan waktu sebelumnya.

Perilaku produktif tersebut dapat dilihat pada tataran yang dimunculkan pada perubahan yang diharapkan, antara lain:

Pertama, tidak hidup menggelandang lagi. Kembalinya gelandangan di kehidupan normal di tengah masyarakat memerlukan proses didik yang perlu dipaksakan. Razia dengan menampung mereka pada panti tertentu, yang nantinya akan diberi bekal keterampilan sehingga timbul kesadaran untuk mengubah hidup dan menggelandang kearah hidup normal.

Kedua, memiliki mata pencaharian yang akan menopang kebutuhan hidupnya. Kegagalan gelandangan untuk hidup normal lebih disebabkan karena mereka tidak memiliki sumber penghasilan lewat pekerjaan yang mampu mereka lakukan. Atau miskinnya keterampilan 
menyebabkan mereka menggelandang lagi. Oleh karena itu, usaha Pemerintah Kota Mataram melakukan koordinasi dengan Dinas Sosial yang menangani para gelandangan merupakan usaha membekali mereka agar mampu menciptakan lapangan kerja atau setidaknya mau bekerja pada orang lain sebagai usaha mencari penghasilan untuk memenuhi kebutuhan hidupnya. Dengan terpenuhinya sasaran ini akan menciptakan kondisi kehidupan mereka yang lebih sejahtera daripada sebelumnya.

Ketiga, mengembalikan harkat sebagai warga Negara dengan hak dan kewajiban yang sama. Keinginan untuk hidup normal di tengah masyarakat membawa dampak meningkatnya rasa percaya diri seseorang dan hidup menggelandang ke tingkat yang lebih balk. Akibatnya, motivasi mereka untuk bekerja akan tumbuh searah dengan sasaran yang ingin dicapainya.

b. Kerjasama dengan Dinas Sosial

Kebijakan yang dikeluarkan Pemerintah Kota Mataram dalam menangani gelandangan tidak dapat dilaksanakan sendiri oleh Pemkot, melainkan membutuhkan koordinasi dan kerjasama dengan pihak lain yang mempunyai tujuan yang sama, misalnya ingin mengentaskan gelandangan, mengurangi jumlah gelandangan dan memajukan kesejahteraan mereka. Pihak yang dimaksud adalah Pemerintah Propinsi mempunyai panti rehabilitasi yang dijadikan rujukan bagi gelandangan dan tuna sosial lain yang terkena razia. (Pengemis, gelandangan dan orang terlantar) yang terkena razia akan ditampung di Panti Sosial Bina Karya Selong Lombok Timur, Panti Sosial bina Remaja “ Karya Utama" Mataram di bengkel dan Dinas sosial

Di Panti Bina Karya Selong, Panti Karya Bengkel Mataram dan Dinas Sosial Kota Mataram, gelandangan akan mendapatkan bimbingan dan penyuluhan dari petugas panti. Di sana mereka mendapat fasilitas dari Panti, seperti makan, minum, dan tempat tidur, atau boleh dikatakan panti ini menjadi tempat tinggal sementara selama keluarga belum menjemput dan Dipulangkan oleh pemerintah Kota. Gelandangan yang ditampung di panti tersebut memperoleh pelayanan dan rehabilitasi sosial diberikan pembinaan dan bekal keterampilan. Bekal keterampilan yang diberikan kepada mereka selama di Panti sangatlah berguna, karena mengingat usia mereka yang masih produktif dan masih mampu bekerja, sehingga kelak mereka bisa hidup mandiri.

Selaku menjabat sebagai Staf Rehabilitasi dan kesejahteraan social Dinas Sosial Kota mTaram Bapak Lalu Azhari menerangkan bahwa setelah para gelandangan yang terkena razia langsung di bawa ke Kantor Dinas sosial Untuk di identifikasi, di tanyakan bagi gelandangan yang tidak mempunyai keluarga akan di bawa ke Panti Sosial dan Bagi yang masih mempunyai keluarga Maka akan di pulangakan

"Gelandangan yang kita Kirim kesana adalah gelandangan yang Tidak mempunyai keluarga dan kadang ada juga punya keluarga tapi jauh, sementara tunggu jemputan dari keluarga, kami tampung dulu di sana, kita beri fasilitas seperti layaknya mereka di rumah. Antara lain makan, minum, tempat tidur, pakaian layak pakai, dan kebutuhan sehari-hari lainnya. Saya rasa semuanya sudah kita Siapkan itu semua". (Hasil wawancara Informan 3)

Tidak semua gelandangan yang terkena razia yang di tampung di Panti Sosial, tapi sebagian saja. Yaitu gelandangan yang benar benar tidak mempunyai keluarga.

"Memang kita jarang memberi mereka uang selama mereka disini, karena masalah terbatasnya dana yang kita terima dan Pemerintah Propinsi." (Hasil wawancara Informan 4).

Bahwa Pihak dari pemerintah Kota Mataram sudah memberikan kesejahteraaan yang baik untuk para gelandangan. Dan perintah sudah menunjuk Dinas Sosial sebagai Koordinator dari masalah Sosial.

Dari hasil penelitian diatas, dan dikaitkan dengan teori sifat kebijakan, maka kerjasama Pemerintah Kota Mataram dengan panti Dinas Sosial dalam menangani gelandangan adalah termasuk keputusan kebijakan (policy decisions). Keputusan kebijakan adalah keputusankeputusan yang dibuat oleh pejabat-pejabat pemerintah yang mengesahkan atau memberi arah dan substansi kepada tindakan-tindakan kebijakan publik. Termasuk dalam kegiatan ini adalah menetapkan undang-undang, memberikan perintah perintah eksekutif atau pernyatan-pernyataan resmi, mengumumkan peraturan peraturan administratif atau membuat interpretasi yuridis terhadap Undang-Undang [9].

Kerjasama Pemerintah Kota Mataram dengan Dinas Sosial dan Panti Sosial yang menangani gelandangan termasuk dalam keputusan kebijakan (policy decisions). Gelandangan yang teajaring dalam razia kemudian dibawa atau disalurkanan ke panti untuk diberi pembinaan, bekal keterampilan serta mamperoleh pelayanan dan rebabilitasi sosial. Hal ini terkait dengan kebijakan Pemerintah Kota Mataram untuk menertibkan gelandangan agar tidak berkeliaran lagi di jalan jalan dan dalam rangka mengurus mereka sesuai yang diamanatkan Pasal 34 ayat (1) Undang-Undang Dasar Negara Republik Indonesia Tabun 1945.

Dari hasil penelitian diatas maka kerjasama Pemerintah Kota Mataram dengan Dinas Sosial dan panti Sosial merupakan penanggulangan gelandangan yang dilakukan melalui usaha represif dan usaha rehabilitatif. Hal ini seperti tercantum dalam Pasal 9 sampai dengan Pasal 14 Peraturan Pemerintah Republik Indonesia No. 31 Tahun 1980 tentang Penanggulangan Gelandangan dan Pengemis. 


\section{TEMUAN ATAU DISKUSI}

Kebijakan gelandangan, pengemis dan anak jalanan di kota Mataram cukup memberikan dampak perbaikan dan menertibkan anak jalanan. Kebijakan yang digunakan adalah tuntutan-tuntutan kebijakan (policy demands), keputusan-keputusan kebijakan (policy decisions) dan hasil-hasil kebijakan (policy outputs), serta dampak-dampak kebijakan (policy outcomes)[11]. Berdasarkan adanya kebijakan tentang gelandangan, maka implementasi kebijakan tersebut dapat terlihat pada kegiatan yang dilakukan Satpol PP dan aparat lainnya merazia pada gelandangan yang bersebaran di jalan utama yang jumlah kendaraan cukup padat, disitulah mereka berada, adanya kegiatan tersebut berguna untuk mentertibkan gelandangan untuk dikarantina dan diberikan rehabilitasi melalui program Rumah Singgah dan Kerjasama pemerintah dengan panti sebagai tempat penampungan gelandangan.

Razia yang dilakukan terhadap gelandangan bertujuan, antara lain untuk:

a) Meningkatkan harkat gelandangan yang tercapai melalui hidup layak dan normal yang telah ditunjukkan dalam kesehariannya.

b) Meningkatkan kesejateraan gelandangan sebagai akibat teerhadap bakat dimilikinya keterampilan dan kemampuan bekerja yang dapat memperoleh penghasilan yang dapat dipergunakan untuk memenuhi kebutuhan hidup masa depannya.

c) Membebaskan Iingkungan dari gangguan sosial yang menyebabkan kenyamanan hidup masyarakat terjamin tanpa gangguan yang berarti.

Dengan demikian razia tersebut bermanfaat bagi segala pihak yang bersangkutan dan terciptanya kondisi normal di tengah kehidupan masyarakat.

Gelandangan harus diberikan perhatian yang baik oleh pemerintah ataupun negara, karena mereka memiliki hak untuk mendapatkan pendidikan, kesejahteraan dan perlindungan. UU No. 35 Tahun 2014 Tentang Perubahan atas UU No. 23 Tahun 2002 tentang Perlindungan Anak Pasal 69, 71 Perlindungan Khusus. dilakukan melalui upaya [12]:

a. penanganan yang cepat, termasuk pengobatan dan/atau rehabilitasi secara fisik, psikis, dan sosial,serta pencegahan penyakit dan gangguan kesehatanlainnya;

b. pendampingan psikososial pada saat pengobatan sampai pemulihan;

c. pemberian bantuan sosial bagi Anak yang berasal dari Keluarga tidak mampu; dan

d. pemberian perlindungan dan pendampingan pada setiap proses peradilan

Berdasarkan undang-undang tersebut, anak jalanan, pengemis memang harus diberikan perlindungan, pelayanan yang baik. Dalam undang-undang nomor 35 tahun 2014 tentang perlindungan anak, pendidik harus memberikan pendidikan dan pelayanan kepada anak secara efektif dan tidak diperbolehkan memberikan hukuman fisik. Demikian juga pada gelandangan harus diberikan pelayanan yang baik tanpa ada tekanan fisik atau melukai mereka [13].

Atas dasar kebijakan tersebut maka pemerintah kota Mataram mengeluarkan kebijakan penanganan anak gelandangan untuk berikan rehabilitasi berupa pembinaan program loka karya, pendampingan mental dan psikologis dan latihan magang. Adapun realisasi kebijakan tersebut sehingga berdampak kepada adanya peningkata kesejahteraan gelangan, yaitu:

1) Pembinaan program loka karya

Pembinaan program loka karya meliputi kegiatan kursus otomotif, kursus komputer, kursus menjahit, dan kursus tata boga.

2) Pendampingan mental dan psikologis

Pendampingan mental dan psikologi terhadap gelandangan snagat penting karena gelandangan yang ada tersebut berbeda masalah psikologisnya karena sebagian mereka tertimpa masalah broken home, orang tua pergi keluar negeri. Dengan latar belakang psikologis mereka cukup menurun dan semangat hidup berkurang (mental kurang sehat). Maka langkah yang dilakukan yaitu memberikan penguatan keagamaan, seperti membaca al-qur`an, mendengar ceramah agama, berolahraga dan memberikan motivasi yang tinggi kepada mereka agar mampu bertahan hidup dan memiliki cita-cita yang berguna untuk diri sendiri dan dapat bekerja dengan baik.

3) Pelatihan magang

Pelatihan magang dilakukan pada gelandangan yang telah mengikuti berbagai kursus ketrampilan keahlian untuk melaksanakan praktek dan ujicoba kemampuan mereka setelah diberikan pembinaan ketrampilan kurusus.

4) Upaya rehabilitasi

Upaya rehabilitasi merupakan usaha memberikan pendampingan berbagai materi penguatan motivasi, penanaman nilai ibadah dan pemberdayaan para anak gelandangan. Dalam memberikan rehabilitasi pada gelandangan meliputi Pembinaan / Rehabilitasi perilaku bertujuan untuk pemmberikan perubahan perilaku anak, Pembinaan / Rehabilitasi karya bertujuan untuk memberikan pembinaan menghasilkan ketrampilan yang produktif, Pembinaan / Rehabilitasi sosial psikologi bertujuan untuk membina mintal anak

Jadi kebijakan pemerintah kota Mataram cukup baik karena mampu menciptakan sumber daya manusia yang berguna dan mampu meningkatkan kesejahteraan gelandangan melalui program loka karya. Rehabilitasi pendidikan bertujuan untuk memberikan ilmu pengetahuan melalui upgrading dan refreshing dalam upaya mendikung berbagai model keterampilan [14]. Masalah gelandangan dan pengemis terletak pada berbagai masalah yang dialami mereka, dimana mereka memiliki mental yang kurang sehat, tidak tidak rajin, 
sulit mau berubah dalam memperbaiki kehidupannya [5].

Terkait dengan gelandangan yang ditangani dinas Sosial dan Panti maupun gelandangan yang sudah kembali ke masyarakat, bahwa adanya kerjasama Pemerintah Kota Mataram dengan Dinas Sosial dan Panti Sosial dalam penyaluran dapat dilaksanakan dengan baik. Gelandangan yang terjaring dalam razia tersebut memang langsung dibawa ke Dinas Sosial dan langsung disalurkan langsung ke Panti Sosial yang sudah di tunjuk Dinas Sosial untuk menangani gelandangan untuk memperoleh pelayanan dan rebabilitasi sosial. Di panti itu mereka akan memperoleh pelayanan dan rehabilitasi sosial yang akan berguna bagi mereka bila sudah disalurkan ke masyarakat.

Kerjasama antara pemerintah dan panti sosial memiliki peran penting dalam memberikan pelayanan, rehabilitasi terhadap gelandangan seperti pembinaan, pendampingan dan pelatihan serta pemberdayaan kepada anak gelandangan mulai pra rehabilitasi, rehabilitasi dan outcome rehabilitasi [15]. Dalam menjamin kerjasama dalam menangani anak gelandangan, tuna wisma, pengemis dibutuhkan sarana dan prasana yang memadai agar menghasilkan nilai yang baik. Penelitian ini sejalan dengan pendapat menyatakan bahwa implementasi Peraturan Daerah No 9 Tahun 2012 Tentang penanganan gelandangan, pengemis, tuna susila, dan anak jalan telah berjalan dengan baik, namun belum sesuai dengan yang tertuang di Peraturan Daerah No 9 Tahun 2012. Dinas Sosial dan Tenaga Kerja terkait sudah menangani gelandangan dan pengemis untuk tuna susila dan anak jalanan terlaksan secara maksimal. Penanganan yang dilakukan yaitu Penertiban, penampungan sementara dan usaha rehabilitasi [2]. Lainnya berpendapat bahwa penertiban gelandangan dan pengemis, sesuai dengan Peraturan Daerah No. 12 Tahun 2008 tentang ketertiban social, dilakukan dengan cara razia oleh Satpol PP dan Dinas Sosial dan Pemakaman. Sedangkan pola pembinaan gelandangan dilakukan menggandengkan panti social milik Pemerintah Daerah dan/ atau panti swasta dan/atau pengembalian bagi mereka yang berasal dari luar Kota [16].

Penangan gelandangan harus aturan tersendiri sesuai dengan ciri khas daerah, sumber daya manusia yang memadai, Balai Rehabilitasi Sosial milik pemerintah, lembaga swadaya masyarakat yang menangani masalah gelandangan dan pengemis dan kerjasama lintas provinsi antar pemerintah Daerah dalam penanganan gelandangan dan pengemis berasal [17]. Jadi implementasi Undang-undnag tentang gelandangan di kota Mataram cukup baik karena pemerintah menyiapkan Rumah Singgah. Dalam Rumah Singgah tersebut para gelandangan diberikan pelayanan dan program rebabilitasi sosial selama di panti itu dapat menjadi modal mereka untuk bekerja mencari nafkah agar dapat hidup layak, sehingga dapat meningkatkan kesejahteraan mereka.

\section{E. SIMPULAN DAN SARAN}

Implementasi kebijakan pemerintah kota Mataram tentang gelandangan dapat dibagi dua, yaitu keputusan kebijakan dan pernyataan kebijakan. Kebijakankebijakan yang dikeluarkan Pemerintah Kota Mataram tentang gelandangan antara lain; Perencanaan pembangunan Rumah singgah di Kota Mataram dan Kerjasama Pemerintah Kota Mataram dengan Dinas Sosial dan Panti Sosial yang menampung Gelandangan. Jadi Pemerintah Kota Mataram sudah mengeluarkan beberapa kebijakan tentang gelandangan, ada kebijakan yang dapat diimplementasikan dan ada pula yang belum dapat diimplementasikan baik oleh pemerintah maupun oleh masyarakat. Jadi adanya kebijakan tersebut bisa mengatasi berbagai permasalahan gelandangan. Kajian penelitian berikutnya dapatmenjelaskan implementasi pada bidang lainnya yang berkaitan dengan masalah konflik sosial anak jalanan.

\section{UCAPAN TERIMA KASIH}

Penulis mengucapkan terima kasih kepada semua pihak yang telah membantu menyelesaiakan penelitian ini yang senantiasa memberikan data dan informasi kepada penulis sehingga penelitian ini selesai dengan baik.

\section{DAFTAR RUJUKAN}

[1] M. A. Tajuddin, "Perilaku Ngelem Aibon Pada Anak Jalanan Di Kota Merauke Dari Perspektif Kriminologi," Law Rev., vol. 17, no. 3, pp. 297-316, 2018.

[2] W. Damayanti and M. Adnan, "Implementasi Kebijakan Penanggulangan Gelandangan dan Pengemis Di Kabupaten Demak Berdasarkan Peraturan Daerah Nomor 2 Tahun 2015," J. Polit. Gov. Stud., vol. 6, no. 3, pp. 161-170, 2017.

[3] C. A. Prasasi, A. L. W. Lita Tyesta, and R. Herawati, "Pelaksanaan Peraturan Daerah Kota Semarang Nomor 5 Tahun 2014 Tentang Anak Jalanan, Gelandangan Dan Pengemis," Diponegoro Law J., vol. 5, no. 2, pp. 1-15, 2016.

[4] A. Rohman, "Program Penanganan Gelandangan, Pengemis, dan Anak Jalanan Terpadu Melalui Penguatan Ketahanan Ekonomi Keluarga Berorientasi Desa," Kementeri. Sos. RI, Jakarta, 2011.

[5] R. Murni, "Peran Jejaring Kerja Dalam Pelaksanaan Pelayanan dan Rehabilitasi Sosial Terhadap Gelandangan dan Pengemis di Panti Sosial Bina Karya Pangudi Luhur Bekasi," Sosio Konsepsia, vol. 5, no. 2, pp. 45-65, 2016.

[6] E. Sastraatmadja, "Ekonomi Pertanian Indonesia," Bandung: Angkasa, 1984.

[7] P. Setijo, Pendidikan Pancasila Perspektif Sejarah Perjuangan Bangsa: Dilengkapi dengan UndangUndang Dasar 1945 Hasil Amandemen. Grasindo, 2006.

[8] P. Y. N. Indro, "Kemiskinan Global Dalam Prespektif'Development as Freedom'Amartya Sen Kasus: Indonesia," J. Ilm. Hub. Int., vol. 9, no. 1, 2013.

[9] B. Winarno, Kebijakan publik: teori, proses, dan studi kasus: edisi dan revisi terbaru. Center for Academic 
Publishing Service, 2012.

[10] J. M. Sihombing and D. A. Sukmoko, Kekerasan terhadap masyarakat marginal. Narasi, 2005.

[11] N. Aprilianda, "Perlindungan anak korban kekerasan seksual melalui pendekatan keadilan restoratif," Arena Huk., vol. 10, no. 2, pp. 309-332, 2017.

[12] R. D. Putro and J. Sutarto, "Pembinaan Pengemis, Gelandangan, Dan Orang Terlantar Dibalai Rehabilitasi Sosial 'Samekto Karti' Pemalang," $J$. Nonform. Educ. Community Empower., vol. 4, no. 2, 2015.

[13] Z. Bidaya and M. Rangga, "Kajian Yuridis UndangUndang Nomor 35 Tahun 2014 Tentang Perlindungan Anak dalam Perspektif Pendidikan," Civ. PendidikanPenelitian-Pengabdian Pendidik. Pancasila dan Kewarganegaraan, vol. 7, no. 2, pp. 48-58, 2019.

[14] T. M. Anggriana and N. K. Dewi, "Identifikasi Permasalahan Gelandangan dan Pengemis di UPT Rehabilitasi Sosial Gelandangan dan Pengemis," Inq. J. Ilm. Psikol., vol. 7, no. 1, 2016.

[15] M. Mambang and W. F. Harry, "Implementasi Kebijakan Gelandangan, Pengemis, Tuna Susila Dan Anak Jalanan Di Kota Palangka Raya Provinsi Kalimantan Tengah," Pencerah Publik, vol. 3, no. 2, pp. 1-8, 2016.

[16] M. Muslim, "Penanggulangan Pengemis Dan Gelandangan Di Kota Pekanbaru," J. El-Riyasah, vol. 4, no. 1, pp. 24-35, 2013.

[17] A. Jahidin, "Model Sistem Rujukan Gelandangan dan Pengemis di Camp Assesment Dinas Sosial DIY," EMPATI J. Ilmu Kesejaht. Sos., vol. 6, no. 1, pp. 39-54, 2017. 